INJURLENS

\title{
REGIONAL POLICY IN MANAGING OIL PALM WASTE AS RENEWABLE ENERGY IN SOUTH KALIMANTAN PROVINCE
}

\author{
${ }^{[1]}$ Ifrani; ${ }^{[2]}$ Muhammad Topan; ${ }^{[3]}$ Nurmaya Safitri ${ }^{[4]}$ Tiya Erniyati \\ Faculty of Law, Lambung Mangkurat University \\ Jl.Brigjen Hasan Basry, Kota Banjarmasin 70123 \\ [1] Email: ifrani@ulm.ac.id \\ [2] Email: mtopan1980@ulm.ac.id \\ ${ }^{[3]}$ Email: mayasafitri94@gmail.com \\ ${ }^{[4]}$ Email: tiya.erniyati@ulm.ac.id
}

Citation: Ifrani; Topan, M.; Safitri, N.; T. Erniyati. 2021. Regional Policy in Managing Oil Palm Waste as Renewable Energy in South Kalimantan Province. Int' Journal of Law, Environment, and Natural Resources (INJURLENS), 1(1), April, 1-10,

Academic Editor: M. Yasir Said Received: 10 February 2021

Revised: 25 February 2021

Accepted: 10 March 2021

Published: 11 March 2021

Publisher's Note: Scholar Center stays neutral with regard to jurisdictional claims in published maps and institutional affiliations.

\section{(c) (1) ()}

Copyright:

(c) 2021 by the authors. Submitted for open access publication in International Journal of Law, Environment, and Natural Resources (INJURLENS) under the terms and conditions of the Creative Commons AttributionNonCommercial-ShareAlike 4.0 license (CC BY NC SA 4.0). For more information visit (http://creativecommons.org).

\begin{abstract}
Besides producing CPO and KPO, oil palm also produces a lot of waste. Oil palm waste can be managed and utilized. This study aims to determine how oil palm waste is managed, the authority of local governments to regulate oil palm waste management in South Kalimantan Province. Third, what is the concept of future local government policies in utilizing oil palm waste as a new and renewable energy development in South Kalimantan? The research method used is normative juridical research, the research that is focused on examining the application of the rules or norms in positive law, analyzing in-depth and holistically, from all aspects comprehensively, sourced from library research using legal materials, namely primary legal materials, secondary legal materials, and tertiary legal materials, to answer regulatory issues in the legislation regarding the Policy on the Use of Oil palm Waste as New and Renewable Energy in South Kalimantan Province. The result shows that Indonesia has been able to create renewable energy from the oil palm industry. However, the government needs to regulate the use of oil palm shell waste through local regulations and policies. With the participation of policymakers, and focus for development. It can creates jobs, increase and develop disadvantaged areas and in the end will reduce the level of poverty.
\end{abstract}

Keywords: Policy; Waste; Renewable energy; Oil Palm Tree.

\section{INTRODUCTION}

One of the plantation commodities that have the potential to be developed in Indonesia is oil palm. In the last 10 years, the Oil palm Factory in Indonesia has grown very rapidly. Most of the plantation lands throughout Indonesia are gradually being converted or transformed into oil palm plantations. An example is the sugar cane plantation owned by the Sugar Factory in Pelaihari District, South Kalimantan, which has been converted into land for oil palm plantations. and there are still many lands belonging to forestry or the people which have been transformed into large oil palm plantation areas. 
The area of oil palm itself in Indonesia in 2018, according to the Directorate General of Plantation and the Ministry of Agriculture, reached 14.03 million hectares. Indonesia's oil palm production level is around 37.8 million tonnes with average productivity of around 3.6 tonnes per hectare. This data has increased when compared to the previous year. For example, in 2016 the area of oil palm land was 11.67 million hectares $(\mathrm{Ha})$, this number consists of smallholder plantations of 4.76 million hectares, private plantations of 6.15 million hectares, and state plantations of 756 thousand hectares. Based on data from the Directorate General of Plantation, Ministry of Agriculture. In the last ten years, the land area for oil palm plantations has increased by an average of 5.9 percent. The highest increase in oil palm land was in 2011, amounting to 7.24 percent to 8.99 million hectares.

In South Kalimantan, it was noted that the area of oil palm plantations and the amount of production per year continued to increase from 2015 to 2017. The details can be seen based on the table below:

Table 1. Oil Palm Production Between 2015-2017

\begin{tabular}{|l|l|l|}
\hline Year & Plantation Area & Total Production/year \\
\hline 2015 & $80.732 \mathrm{Ha}$ & 188.277 Ton \\
\hline 2016 & $83.865 \mathrm{Ha}$ & $190.936 \mathrm{Ton}$ \\
\hline $\mathbf{2 0 1 7}$ & $85.509 \mathrm{Ha}$ & $195.152 \mathrm{Ton}$ \\
\hline
\end{tabular}

In South Kalimantan, there are 64 plantation companies with concession areas of more than 500,000 hectares. In the management of oil palm plantations, it does not only pay attention to the source of water reserves and the use of local community labor but also to the output from waste and how to use the waste properly. For example, PT Hasnur Citra Terpadu, through its commissioner Hasnuryadi Sulaiman, said that the company plans to build a power plant using waste fuel and palm kernel shells. PT Hasnur Citra Terpadu is a plantation company operating in the Tapin Regency area, with a plantation area of 8,200 hectares. The company's CPO mill is targeted to start operating in 2012.

Besides producing $\mathrm{CPO}$ and KPO, oil palm also produces a lot of waste. Oil palm waste can be managed and utilized. Research on the utilization of oil palm waste has been carried out by experts in the fields of chemistry, engineering, and agriculture. From the results of this study, it was found that the utilization of oil palm waste was found. for example, the utilization of oil palm waste into electricity, biogas, making organic fertilizers, animal feed ingredients, making paper pulp, charcoal, etc. This becomes interesting, for example, the use of fuel for the power plants, because so far, power plants use oil or coal to turn turbines. Meanwhile, oil and coal are consumable fuels that take millions of years to be reused.

In 2019, Balitbangda of South Kalimantan Province held a Seminar discussing the study of findings of renewable energy sources from oil palm shells. This makes the 
plantation sector and oil palm production in South Kalimantan continue to grow and has a positive potential. Besides, South Kalimantan, as one of the oil palm-producing areas in Indonesia, has made oil palm the second largest contributor to Regional Original Income after coal. Oil palm shell itself is a major waste of oil palm management. The prospect of utilizing waste is aimed at making the largest biomass gasification by utilizing oil palm shells, from 17.5 kilograms of shells, capable of replacing 7 liters of fuel oil which produces $100 \mathrm{~kg}$ of steam/hour.

Regarding the geography of South Kalimantan which is dominated by remote areas and swamp forests, most of which have not yet been electrified, the utilization of oil palm waste to fuel power plants is an important agenda that needs to be considered by local governments. The utilization of oil palm waste for power generation fuel is a renewable energy source. To overcome the energy deficit problem in Indonesia, the development of renewable energy sources is a must. To this demand, the oil palm industry has a very large potential contribution. The problem is how far the local government authority can regulate oil palm waste management in South Kalimantan? and what policies local governments should take in utilizing oil palm waste as a form of support for policies that support the development of renewable energy in Indonesia.

\section{METHODS}

The type of research used is normative legal research, which is the research focused on examining the application of the rules or norms in positive law, (Ibrahim: 2005) analyzed in-depth and holistically which means from all aspects comprehensively. (Sulaiman: 2012) Sourced from literature research that uses legal materials, namely primary legal materials and secondary legal materials to answer regulatory issues in legislation regarding the Policy on the Use of Oil palm Waste as New and Renewable Energy in the Province South Kalimantan (Nurhayati, Ifrani, Said, 2021).

This research is focused on the implementation and the authority of regional government according to Act 9/2015 on Regional Government and related laws and regulations in analyzing the problems of oil palm waste in South Kalimantan. The type of legal research carried out is an inventory of the laws and regulations on oil palm waste management, particularly in South Kalimantan.

Research conducted using primary data and secondary data (Wignjosoebroto, 1995). Primary data is research material in the form of empirical facts regarding the existence of oil palm plantations in South Kalimantan as well as an analysis of the extent to which oil palm waste is used in South Kalimantan, especially in areas where oil palm plantations are located. Primary data is needed in this study to strengthen/clarify secondary data. Secondary data is legal material in research obtained through library research consisting of primary legal materials, secondary legal materials, and materials, non-legal materials (See Soekanto, 1981; Soekanto \& Mamudji, 2003). 


\section{RESULTS AND DISCUSSION}

\subsection{The Concept of Zero Waste as One of the Efforts to Use Oil Palm Waste}

The Oil palm (Elaeis guineensis Jacq.) Is a plantation commodity that plays an important role in the Indonesian economy as a significant contributor to non-oil and gas foreign exchange. Oil palm produces processed products that have many benefits (Lubis, 1992). As explained above, the area of oil palm plantations continues to increase every year, with large oil palm plantations accompanied by high export volumes, this is because world demand for oil palm continues to increase so that the export market is always wide open and could provide great profits (Goenadi, 1998).

The increase in demand for oil palm and its derivatives must be balanced with an increase in oil palm production. The efforts to increase oil palm production are pursued by expanding the area of oil palm plantations and increasing productivity (Silalahi, 2017). The increase and expansion of oil palm plantation areas arefollowed by an increase in the number of processing industries, which causes the amount of waste produced to increase as well (Sulaeman, 2008). This is due to the increasing weight of oil palm Factory waste that must be disposed of. The waste generated from the oil palm cultivation process will harm the environment, the number of natural resources, the quality of natural resources, and the environment.

With the negative impact of waste generated from industry, it requires factories to be able to treat waste in an integrated manner (Sugiharto, 1987). In the development of the oil palm industry, it is called the development of an integrated oil palm factory (PKS). The use of waste into profitable materials or have high economic value is carried out to reduce negative impacts on the environment besides creating an environmentally friendly industry (Pahan, 2007). Therefore, the application of the concept of zero waste in the plantation business is highly recommended.

As for a brief explanation regarding the Zero Waste Concept, based on its definition, what is meant by zero-waste activity is "the activity of eliminating waste from a production process through integrated production process management with minimization, segregation, and waste treatment" (Loekito, 2002). In other words, industry players must strive to minimize the waste which is produced and if the waste is still generated, efforts should be made to obtain it so that it becomes a product that is safe but still has economic value (Septiawana, 2014). In terms of the production process, it is necessary to pursue pollution prevention activities that can have negative impacts on the environment, to the number of natural resources, the quality of natural resources, and the environment (Dede, 2008).

In this case, eliminating waste can be done in two ways, which are: First, running an efficient-effective production process with the support of optimum production supporting factors. It is theoretically and practically impossible to eliminate $100 \%$ of waste from the production process. Even with the most optimum level of efficiency-effectiveness, waste will still be produced, but the amount will be very small. This small amount of waste must then be managed properly so as not to pollute the 
environment. Second, treating the resulting waste if there are limitations in achieving efficient-effective conditions in the production process. By treating waste, the waste becomes non-existent. A better perception is when the waste is seen as a raw material for producing certain goods which are of course economic value.

If the concept of zero waste is implemented properly and correctly in every oil palm company, it is not only the oil palm that can provide a lot of economic value but the waste can also generate beneficial benefits for the company. Also, the negative impact on the environment due to oil palm waste can also be reduced. Indeed, consciously, the problem regarding the waste can always be not separated from the negative impacts that it produces, especially from the environment in which people live.

The people and the environment are always living side by side, this is clearly stated in Article $28 \mathrm{H}$ paragraph (1) "Every person shall have the right to live in physical and spiritual prosperity, to have a home and enjoy a good and healthy environment, and shall have the right to obtain medical care." This article is the basis that protection of the environment is guaranteed recognition by the state. The form of recognition is the inclusion of the right to the environment in the 1945 Constitution of the Republic of Indonesia. So that in this case, the right to a clean and healthy environment is an inseparable part of human rights.

\subsection{Oil Palm Waste Management as Renewable Energy}

The Oil palm industrial waste contains a lot of organic and inorganic compounds. Organic compounds are more easily broken down than inorganic compounds. Organic compounds can be broken down by bacteria both aerobically and anaerobically. The difficulty of waste to be overhauled affects environmental sustainability (pollution load). Oil palm waste contains toxic substances such as heavy metals (copper, lead, silver, zinc, iron, nickel, etc.) which can adversely affect microorganisms (Sugiharto, 1987). On the other hand, the organic material contained in oil palm processing waste is a potential raw material that has economic value and can be used to increase plant production.

Oil palm plantations and factories produce large amounts of solid and liquid waste which have not been optimally utilized. Fiber and some oil palm shells are usually used for boiler fuel in factories, while oil palm empty bunches (TKKS), which is around $23 \%$ of the processed fresh fruit bunches, are usually only used as mulch or compost for oil palm plants (Goenadi et al., 1998).

The interesting thing about the use of waste from oil palm processing is that this waste can be used as renewable energy. As we know today that the life activities, especially for urban communities cannot be separated from electrical energy, in other words, the dependence of people on the availability of electrical energy is very high. Almost every work equipment and support for the office, household, and business activities require electrical energy, so if the supply of electrical energy is disrupted, it will have a direct impact on the socio-economic activities of the community. 
Many oil palm companies use oil palm waste as electrical energy, for example in West Kalimantan. In fact, in the West Kalimantan region, currently, the supply of electrical energy is still largely dependent on diesel power plants (PLTD). This makes it very dependent on energy sources for fuel oil (BBM), and the impact that it has is the bloating of the state budget for fuel subsidies. Besides, the economic crisis that was triggered by the rising of world oil prices has to make feared by the people of Indonesia. Therefore, dependence on fuel naturally needs to be gradually reduced. This is a challenge in itself for us to find renewable energy sources that have not been used optimally.

In short, solid and liquid waste produced by oil palm processing factories in West Kalimantan can be used as a source of electrical energy to meet the operational needs of the factory and the surrounding community. The utilization of oil palm waste ideally goes through several processes from fresh fruit bunches (FFB) to CPO and palm kernel will produce solid waste in the form of empty fruit bunches, fiber, shell, and liquid waste POME (oil palm factory effluent). Solid and liquid waste produced by oil palm processing plants can provide added value if processed with the right touch of technology. Along with the issue of global warming and the increasing need for energy, the use of solid waste and liquid waste from oil palm processing as an energy source will provide added value that is more profitable compared to utilization for other products (Fauzi, 2017; Fauzi, 2012). The utilization of oil palm processing factory waste into electricity will get two benefits, energy sales to PLN and carbon emission reduction contracts (CER). The cost of generating electricity based on waste from oil palm processing plants is much cheaper than diesel power plants (Fauzi, 2017).

\subsection{The Future Policy for Oil Palm Waste as Renewable Energy in South Kalimantan Province}

The development always brings positive and negative impacts and changes. The positive impact is one of the goals of the implementation of development, which is positive changes for humans in achieving their welfare (Fuady, 2010). Regarding the concept of sustainable development, it appears not only in Indonesia but also throughout the world, especially in developing countries (Rompas, 2017).

The definition of sustainable development according to Act 32/2009 is a planned conscious effort that integrates environmental, social, and economic aspects into a development strategy to ensure environmental integrity as well as safety, capabilities, welfare, and quality of life for present and future generations (Marhaeni, 2012). Associated with the concept of sustainable development, this is in line with the development of the oil palm industry in Indonesia. Knowing the oil palm industry has become a strategic industry in national and even world development. The oil palm industry needs to be seen and placed as part of the solution to achieving the Sustainable Development Goals (SDGs). 
The Sustainable Development Goals (SDGs) is a global action plan agreed upon by world leaders, including Indonesia, to end poverty, reduce inequality and protect the environment. Indonesia and the world. In the process of achieving the goals of the Sustainable Development Goals, the oil palm industry is an important factor that must be considered by policymakers. In short, positioning the oil palm industry as an actor of the Sustainable Development Goals (SDGs) can creating solutions, as well as strengthen the oil palm industry itself.

The waste from oil palm processing can be used as renewable energy in Indonesia. This goes along with Indonesia which is facing a fairly basic energy problem. In addition, the level of availability of non-renewable energy sources is also decreasing. To overcome the energy deficit problem, the development of renewable energy sources is a must. Towards this demand, the oil palm industry has a very large potential contribution. The oil palm waste products such as shells and CPO factory waste have potential as a source of biomass that can be converted into renewable energy. This alternative has several advantages such as renewable energy sources so that it can guarantee sustainable production, eco-development and optimize the use of resources and increase added value.

With the advantages and readiness of the oil palm plantation industry as renewable energy, the government no longer needs to look for other alternatives for energy reserves. The government only needs to have a high and consistent commitment to this industry and work hard so that later this industry can be developed (Asshiddigie, 2007). It must also pay attention to the surrounding environment with human rights. Related to the development of human rights doctrine in the world, according to Karel Vasak, it is strictly divided into 3 (three) generations, which are the first human rights generation that focuses on civil and political rights, the second human rights generation that focuses on rights. economic, social, and cultural, as well as the third generation of human rights that focuses on the development rights, with different characteristics (Andrey, 2014).

In particular, the development of the third generation of human rights which is the result of compromise from the previous two generations reflects a rationale for the emergence of collective rights recognized in the third generation of human rights, including the right to environmental preservation from waste from oil palm processing that can be harmful to health and the environment. Based on the explanation above, Indonesia has been able to create renewable energy from the oil palm industry. However, the government needs to regulate the use of oil palm shell waste through local regulations and policies.

\section{CONCLUSIONS}

The organic material contained in oil palm processing waste is a potential raw material that has economic value and can be used to increase crop production. The waste generated from the oil palm processing process will harm the environment, both the number of natural resources, the quality of natural resources and the environment. 
With the negative impact of waste generated from industry, it requires factories to be able to treat waste in an integrated manner. In the development of the oil palm industry, it is called the development of an integrated oil palm factory (PKS). The use of waste into profitable materials or have high economic value is carried out to reduce negative impacts on the environment, besides that can create an environmentally friendly industry. Therefore, the application of the concept of zero waste in the plantation business is highly recommended. The utilization of oil palm processing factory waste into electricity will get two benefits, energy sales to PLN and carbon emission reduction contracts (CER). The cost of generating electricity based on waste from oil palm processing plants is much cheaper than that of diesel power plants.

It can be concluded that Indonesia has been able to create renewable energy from the oil palm industry. However, the government needs to regulate the use of oil palm shell waste through local regulations and policies. With the participation of policymakers, we hope that there is no longer confusion regarding the regulation of the utilization of oil palm waste. With a high commitment and focus for development, we believe that it will create more benefits, such as the opening of new jobs and further develop disadvantaged areas to reduce the level of poverty.

Author Contributions: "Conceptualization, I. and M.T.; Methodology, I.; Validation, N.S. and M.T.; Formal Analysis, I; Investigation, T.E.; Resources, I; Writing-Original Draft, N.S.; Writing-Review and Editing, N.S.; Supervision, I; Project Administration, N.S; Translation, T.E.

Funding: "This research received no external funding".

Conflicts of Interest: "The authors declare no conflict of interest."

\section{REFERENCES}

\section{Books}

Abdullah Sulaiman, 2012, Metode Penulisan IImu Hukum, YPPSDM, Jakarta.

Andrey Sujatmoko, 2014, Hukum HAM dan Hukum Humaniter, Cetakan Pertama, RajaGrafindo Persada, Jakarta

Brury Marco Silalahi dan Supijatno, 2017, Pengelolaan Limbah Kelapa Sawit (Elaeis guineensis Jacq.) di Angsana Estate, Kalimantan Selatan, Departemen Agronomi dan Hortikultura, Fakultas Pertanian, Institut Pertanian Bogor.

Dede Sulaeman, 2008, Zero Waste (Prinsip Menciptakan Agro-industri Ramah Lingkungan), Pusat Departemen Pertanian, Jakarta.

Fauzi, Y., Widyastuti, Y. E., Satyawibawa, I., \& Paeru, R. H,. 2012. Kelapa Sawit. Penebar Swadaya Grup. 
Fauzi, 2017, Potensi Limbah Perkebunan Kelapa Sawit Sebagai Sumber Energi Alternatif Terbarukan Di Wilayah Kalimantan Barat, Jurnal ELKHA Vol. 9, No 2 ,October 2017

Goenadi, D.H, Y. Away, Sukin, Y., Yusuf, H. H., Gunawan \& Aritonang, P. 1998. PilotScale Compossing of Oil palm Using ligno-cellulosic Decompossing Bioactivator. 1998 International Oil palm Conference. Nusa Dua Bali.

Jimly Asshiddigie, 2007, Pokok-Pokok Hukum Tata Negara Pasca Reformasi, PT. Bhuana Ilmu Popular, Jakarta.

Johnny Ibrahim. 2005. Teori \& Metodologi Penelitian Hukum Normatif. Surabaya : Bayumedia Publishing.

Lubis, A. U. 1992. Kelapa Sawit (Elaeis guineensis Jacq.) di Indonesia. Pusat Penelitian Perkebunan Marihat-Bandar Kuala. Sumatera Utara

Marhaeni. R.S, 2012, Hukum Lingkungan dan Pelaksanaan Pembangunan Berkelanjutan di Indonesia, PT Gramedia Pustaka Utama: Jakarta.

Munir Fuady, 2010, Konsep Negara Demokrasi, Refika Aditama, Bandung.

Pahan, I. 2007, Panduan Lengkap Kelapa Sawit, Jakarta (ID), Penebar Swadaya.

Sugiharto. 1987. Dasar-dasar Pengelolaan Air Limbah. Jakarta (ID): Penerbit Universitas Indonesia (UI-Press).

Soerjono Soekanto dan Sri Mamudji. 2003. Penelitian Hukum Normatif. Jakarta : PT. Raja Garafindo Persada.

Soerjono Soekanto, 1981, Pengantar Penelitian Hukum, UI Press, Jakarta.

Soetandyo Wignjosoebroto, 1995. "Sebuah Pengantar ke arah Perbincangan tentang Pembinaan Penelitian Hukum dalam PJP II", Makalah, disampaikan dalam Seminar Akbar 50 Tahun Pembinaan Hukum Nasional dalam PJP II, BPHN, Departemen Kehakiman, Jakarta.

\section{Journal and Research Report}

Billy Rompas, 2017, "Kajian Yuridis Penyelenggaraan Pemerintah Daerah Oleh Kepala Daerah Berdasarkan UU Nomor 9 Tahun 2015 Tentang Perubahan Kedua Atas Undang-Undang Nomor 23 Tahun 2014 Tentang Pemerintahan Daerah", Jurnal Lex Administratum, Vol. V, No. 5, July 2017.

Brury Marco Silalahi dan Supijatno, 2017, "Pengelolaan Limbah Kelapa Sawit (Elaeis guineensis Jacq.) di Angsana Estate, Kalimantan Selatan Waste management of oil palm (Elaeis guineensis Jacq.) in Angsana Estate, South Kalimantan", Journal Bul. Agrohorti 5 (3) : 373 - 383 (2017), IPB.

Hendra Septiawana, Hariyadib, Machmud Thoharic, 2014, "Analisis Pengelolaan Lingkungan Pabrik Kelapa Sawit Batu AMpar - PT. Smart Tbk. Dalam 
Implementasi Indonesian Sustainable Palm Oil" (Analysis of Environmental Management Palm Oil Mill Batu Ampar - PT SMART Tbk in the Implementation of Indonesian Sustainable Palm Oil)", Jurnal Pengelolaan Sumberdaya Alam dan Lingkungan Vol. 4 No. 2 (December 2014).

Henry Loekito, 2002, "Teknologi Pengelolaan Limbah Industri Kelapa Sawit", Jurnal Teknologi Lingkungan, Vol. 3. No. 3, September 2002.

Yati Nurhayati, Ifrani, M.Yasir Said, 2021, "Metode Normatif dan Empiris Dalam IImu Hukum", Jurnal Penegakan Hukum Indonesia, Vol.2, No.1, Februari 2021.

\section{Internet}

https://id.wikipedia.org/wiki/Kalimantan Selatan

http://ditjenpdt.kemendesa.go.id/potensi/province/12-provinsi-kalimantan-selatan

http://www.jtanzilco.com/blog/detail/604/slug/teknologi-pengolahan-limbah-cair-pabrikkelapa-sawit.

https://ekonomi.kompas.com/read/2018/02/26/203000426/kementerian-pertanian-lahan-sawit-indonesia-capai-14-03-juta-hektare.

Anonim, Statistik Perkebunan Indonesia (Kelapa Sawit 2015-2017) http://ditjenbun.pertanian.go.id/tinymcpuk/gambar/file/statistik/2017/Kelapa -Sawit-2015-2017.pdf

Anonim, Industri Perkebunan Belum Ramah Lingkungan, http://www.bumn.go.id/ptpn5/berita/134 